Zabroda, P., Pshenichnov, L., Marichev, D. (2020). Benthic wildlife underwater video recording during longline survey in Weddell Sea. Ukrainian Antarctic Journal, 2, 75-83.

https://doi.org/10.33275/1727-7485.2.2020.655

\author{
P. Zabroda ${ }^{1}$, L. Pshenichnov ${ }^{1, *}$, D. Marichev ${ }^{2}$ \\ ${ }^{1}$ Institute of Fisheries and Marine Ecology, Berdiansk, 71118, Ukraine \\ ${ }^{2}$ LLC Fishing Company Neptuno, Odessa, 67500, Ukraine \\ *Corresponding author: 1kpbikentnet@gmail.com

\section{Benthic wildlife underwater video recording during longline survey in Weddell Sea}

\begin{abstract}
Non-extractive method for the benthic wildlife study using the underwater video system (UVS) recording was provided during the research survey with the bottom longline in the northwestern part of the Weddell Sea. At the longline survey stations the data on wind direction and speed, state of the sea, air temperature, cloudiness, ice concentration, atmospheric pressure, precipitation, depth and coordinates of the anchor setting, direction of the longline set also were collected. It was found that the UVS with additional light during video recording does not disturb the animal behavior at depths of 700-1100 $\mathrm{m}$ in the study area. Three UVS observations have been described. The slope of the northwestern part of the Weddell Sea can be considered as spawning site of squid (Slosarczykovia circumantarctica). The data indicate wide distribution of Antarctic krill (Euphausia superba) and Antarctic jonasfish (Notolepis coatsi) in the area. The high density of the adult Antarctic jonasfish in a single place has never been recorded before. Preliminary observations and analysis of video recordings showed that the shooting lighting and observation distance are sufficient for observing and identifying animals, their behavior and movement. This technique will allow estimating the relative species abundance and size distribution.
\end{abstract}

Keywords: animal behavior, bottom longline, jonasfish, krill, squid, spawning, underwater video system, Weddell Sea

\section{Introduction}

At the beginning of February 2020, the Ukrainian longline vessel CALIPSO performed the research survey with the bottom longline in accordance with the decision of the Commission for the Conservation of Marine Living Resources (CCAMLR) to estimate the biomass of Antarctic toothfish (Dissostichus mawsoni, Nototheniidae). The research survey was carried out based on the standard rules performed regularly under the responsibility of CCAMLR in the northwestern Weddell Sea of statistical Subarea 48.1. Special attention was paid to test and use a deep-sea video system to capture benthos video data. The studies using similar devices were carried out on fishing vessels in the Antarctic and Patagonian toothfishes fishery in the Ross, Mawson and D'Urville Seas (Dunn et al., 2016; Di Blasi et al., 2018; Maschette et al., 2016). In the Weddell Sea (West Antarctica) south of the research survey area by the CALIPSO vessel, video observations were carried out on a remotely operated vehicle (ROV) from the POLARSTERN vessel, Germany (Gutt et al., 2008), and to the east of the area with a near-trawl video camera during shooting with a bottom trawl by a US vessel (Jones \& Lockhart, 2011; Lockhart et al., 2009). In both latter cases, video was collected at the depth less than 800 meters.

In this paper we consider a new for Ukraine UVS non-extractive recording method for the study of the benthic wildlife. Simultaneously with the video record- 


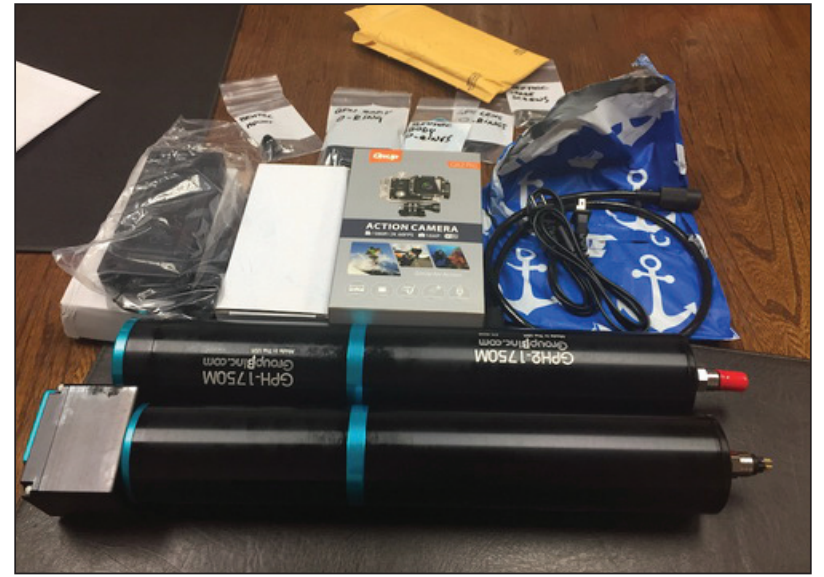

Figure 1. The UVS Benthic 2 GroupBinc kit for deep sea video recording used in the survey

ing, oceanological parameters on depth, temperature and salinity were also recorded using the salinity, conductivity, temperature and depth logger the DST CTD Star-Oddi kit. During the CALIPSO survey at three longline stations, a set of equipment for underwater video recording was attached to the fishing gear the underwater video system (UVS) and three video clips were successfully recorded. These data serve to improve the knowledge of the spatial and temporal distributions of fishes and other Antarctic ecosystem components, which is a criterion of conservation and management of the ecosystem.

\section{Methods}

The underwater video system Benthic 2 GroupBinc kit (https://www.groupbinc.com/) is shown in Fig. 1. The kit included GitUp2 action camera, sealed cylinder for camera with powerful battery, main programmer and camera power stabilizer, sealed cylinder with powerful light-emitting diode (LED) lamp, powerful battery and secondary programmer for the LED lamp operation, two cables, which connect the cylinders and two battery chargers. There were two sets of the UVS equipment on board the vessel. The special stainless steel platforms (frame) were made to accommodate the UVS (Fig. 2a). Before installation (mounting) of the UVS on the fishing gear (longline), the UVS was repeatedly and successfully tested.
According to the technical characteristics, the equipment could be used at a maximum depth of $1750 \mathrm{~m}$. Video recording starts at the moment when the camcorder is immersed into the water and is finished when the battery charge is exhausted. Each camcorder has capacity to keep video recordings at $64 \mathrm{~Gb}$ memory card. The recording time lasts about 4.5 hours with the full high definition format $1920 \times$ $\times 1080$ pixels resolution and the 60 frame per second rate. Each memory card stores $15-16$ videos. The viewing angle of the lens is $120^{\circ}$. The time displayed on the camera and on the DST CTD sensor capsule was synchronized, which also allows to track the scene, depth and the recording time in UTC, while the camera sinks to the seabed. The appropriate distance for identification of the object, for example, fish of $10 \mathrm{~cm}$ size is about $3 \mathrm{~m}$.

The DST recorder in a plastic housing of the DST CTD Star-Oddi kit (Fig. 2b) was attached to the platform with video equipment to collect oceanological data: depth, temperature and salinity. At the longlines stations, other data were also collected: the wind direction and speed, sea waves, air temperature, cloudiness, ice concentration, atmospheric pressure, precipitation, depth and coordinates of the anchor setting, direction of the longline setting. The camera positioning depth was recorded from the vessel's echo sounder and then updated using the DST STD equipment. Three successful UVS observations were made using the UVS in Subarea 48.5 in Weddell Sea (Fig. 3).

\section{UVS observation station description}

The observation with the UVS equipment has been provided during the CALIPSO research survey with the bottom longline in the northwestern Weddell Sea of CCAMLR Subarea 48.1 at the beginning of February 2020 at three survey station with numbers according to the longline survey scientific program.

Station 1. Date of operation, 2 February 2020. The approximate time period of UVS operation 23:3004:00 UTC, wind direction SW, speed $8 \mathrm{~m} / \mathrm{s}$, sea condition 1 point, air temperature $0{ }^{\circ} \mathrm{C}$. The water surface temperature was about $0{ }^{\circ} \mathrm{C}$. The water temperature at the bottom was $-0.81{ }^{\circ} \mathrm{C}$. The depth of 

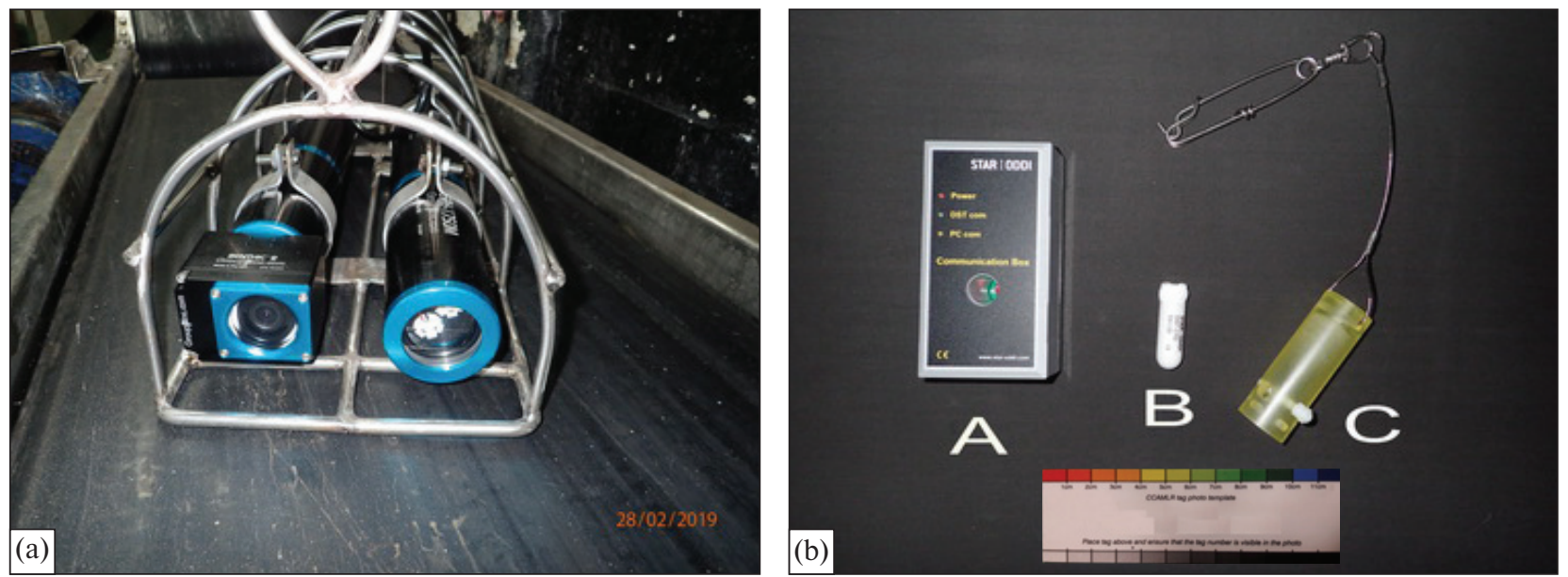

Figure 2. (a) The special platform with the UVS Benthic 2 GroupBinc equipment inside; (b) the DST CTD Star-Oddi kit: A communication box, B - DST CTD recorder logger, C - plastic housing

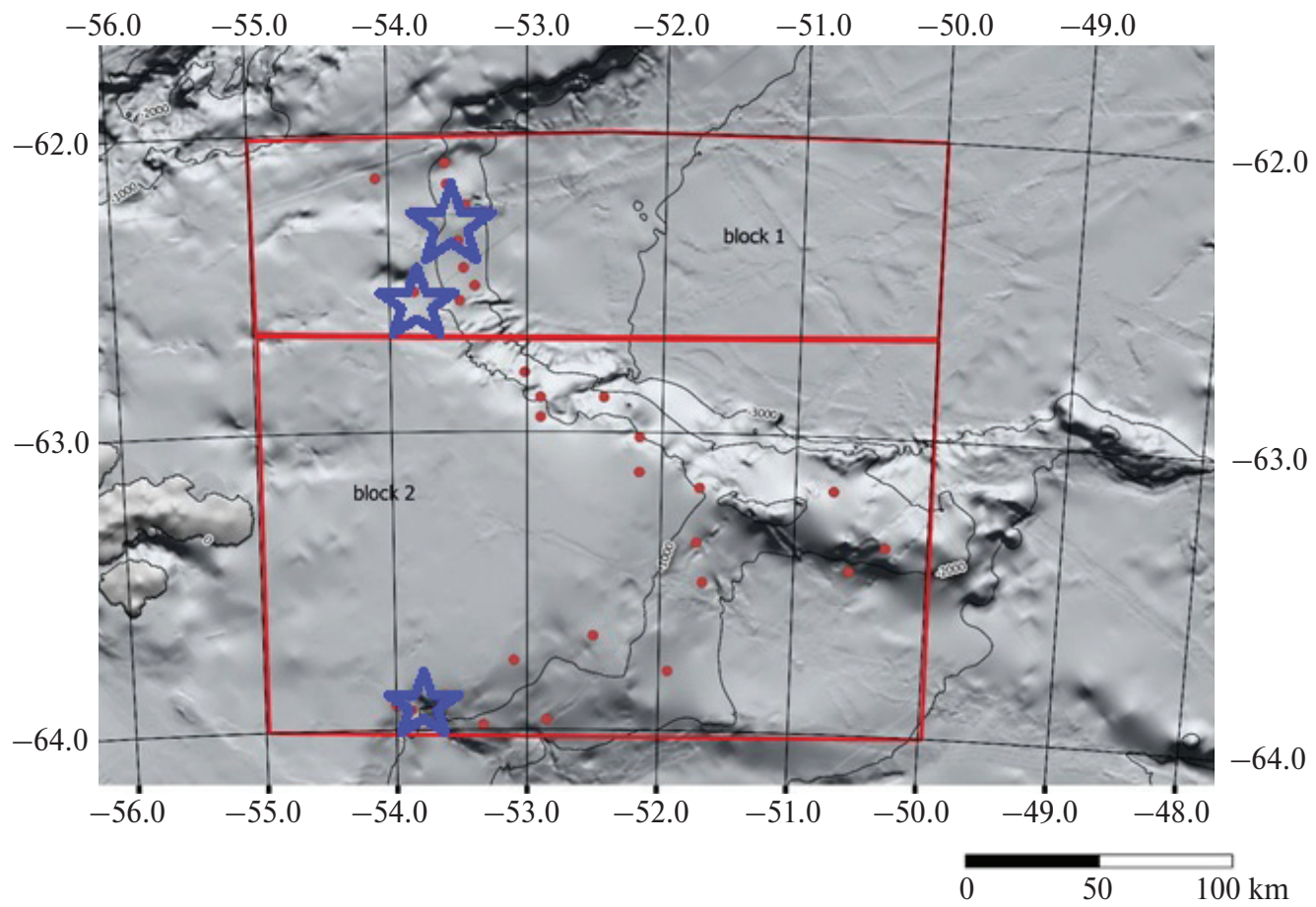

Figure 3. Map of the UVS stations (stars) in Subarea 48.1 in Weddell Sea

the camera set at the bottom 733-736 m. Ice concentration was 4 points in the area of the longline station. The coordinates of the camera exit from the vessel: $63^{\circ} 55^{\prime} \mathrm{S}, 53^{\circ} 53^{\prime} \mathrm{W}$. The camera was attached to a transverse connecting line in proximity to the hook line. Longline setting direction was $57^{\circ}$. The direction of the bottom water current was $320-330^{\circ}$, the current speed was about $1 \mathrm{~m} / \mathrm{s}$. The seabed is flat, rocky. The stones at the seabed are mostly small size. When touched the seabed, the platform with the camera was tilted at an angle of $45-50^{\circ}$. Video shooting at the seabed mainly occurred with tilted video image. 
Station 4. Date of operation, 4 February 2020. Approximate period of operation of the UVS is 14:3019:00 UTC. Wind direction SE, wind speed $6 \mathrm{~m} / \mathrm{s}$, sea condition 3 points, air temperature $0{ }^{\circ} \mathrm{C}$, the water surface temperature about $0^{\circ} \mathrm{C}$. The water temperature at the bottom was $-0.36^{\circ} \mathrm{C}$. The depth of the camera set at the bottom 1115-1118 $\mathrm{m}$. There was no ice in the area of the longline setting. The coordinates of the camera launch from the vessel: $62^{\circ} 30^{\prime} \mathrm{S}, 53^{\circ} 46^{\prime} \mathrm{W}$. The camera was attached to a transverse connecting line in proximity to the hook line. The direction of setting the longline was $146^{\circ}$. The direction of the sea current $-320-330^{\circ}$, and the current velocity was $0.3-$ $0.5 \mathrm{~m} / \mathrm{s}$. The seabed was rocky with an uneven relief and relatively flat section of the seabed. The stones at the bottom are mostly small sized. The platform with the camera when touched the seabed initially was tilted at an angle of $45-50^{\circ}$ then stabilized almost horizontally. Video at the bottom was mainly recorded with camera tilt at 5-10 degrees to the horizon.

Station 9. Date of operation, 7 February 2020. The approximate time period of the UVS operation was 17:00-22:00 UTC, wind direction SE, wind speed $7 \mathrm{~m} / \mathrm{s}$, sea condition 4 points, air temperature $3{ }^{\circ} \mathrm{C}$, the water temperature at the seabed $-0.34^{\circ} \mathrm{C}$. The sea depth was $1032-1034 \mathrm{~m}$. There was no ice in the area where the longline was set, but several icebergs were observed around. The coordinates of the exit from the vessel: $62^{\circ} 20^{\prime} \mathrm{S}, 53^{\circ} 39^{\prime} \mathrm{W}$. The camera was attached to the hook line, longline setting direction $50^{\circ}$. The direction of the bottom water current was of $320-330^{\circ}$, the sea current velocity was of $1.5-2 \mathrm{~m} / \mathrm{s}$. The seabed is rocky with uneven terrain. The stones at the bottom were small and large sized. When touched the seabed, the platform initially was set horizontally, but the field of view was overlapped by a fishing line. Soon, the platform with the camera began to turn over and fell on its side. Video shooting at the seabed mainly occurred in a vertical plane. The field of view was periodically blocked by a fishing line. Most likely one of the floating icebergs on the site captured the buoys of the longline and moved the anchors and the platform with the camera.

The basis of bottom sediments in the observed sites (stations) was the iceberg rafted deposits as small and large size stones. The direction of the sea current was determined by the direction of the longline and by the movement of visible passive particles in the light of the searchlight. The direction of the bottom current corresponds to the published data (Heywood et al., 2014; Garabato et al., 2002; Hellmer et al., 2017; Gordon et al., 2001; Kerr et al., 2018; Orsi et al., 1999; Vernet et al., 2019), where the Weddell Sea Deep Water current in the study area has a north-northwest direction along the mainland slope of the Powell Basin. The recordings were carried out in daytime (Station 4), evening (Station 9) and late evening (Station 1). The coordinates of the descents of the camera from the vessel were recorded. The measured water temperature at the seabed is consistent with literature data (Gordon et al., 2001; Kerr et al., 2018; Orsi et al., 1999; Vernet et al., 2019).

\section{The preliminary results of video survey}

The results of observation and preliminary analysis of video recordings showed that the illumination and distance are sufficient to record behavior, movement and species identification. Surprisingly, the shooting light did not affect the behavior of Antarctic krill, fish, squid and suspension filter feeders (Fig. 4). In this paper the description of the observations was done as incomplete review of the obtained material due to a lot of information obtained. Every few seconds new organisms appeared in the camera field of view and their behavior was diverse. The complete description of the observations will be presented after the detailed review of the entire recordings set.

During the lowering of the UVS from the surface to the bottom, the device was switched on immediately before setting the longline. The small amount of the seston (trypton and plankton) could be observed in the field of view. The sinking speed was more than one meter per second, therefore the identification of the plankton organisms was unavailable. About 100$300 \mathrm{~m}$ above the seabed a lot of organic material as the seston fall appeared in the field of view. At the seabed, this material was moved by the current. From the transport of passive organisms and their remnants, the approximate speed and direction of the near-bottom current was calculated. 
Antarctic krill (Euphausia superba, Euphausiidae) was observed at all three stations at the seabed. Specimens of different sizes (visual assessment) from $3.5 \mathrm{~cm}$ to $5 \mathrm{~cm}$ lengths were observed. Crustaceans swam in different directions both sideways and vertically. The circular motions of crustaceans as vertical circles resembling a Ferris wheels at the bottom were especially remarkable. Often they touched the seabed and raised small clouds of sediments. In the places where the turbidity was raised, rounded particles resembling eggs were seen with relatively large size up to $2-3 \mathrm{~mm}$. Most likely, krill fed on detritus raising clouds of suspended matter, consisting mainly of newly settled detritus most likely with a large number of bacteria, and the feeding process took place in relatively dense clouds of organic remains. The crustaceans sailed within the camera's visibility both from different sides and from above.

Since the UVS was immobile at the bottom, observation of benthic animals was limited. It was possible to observe only animals moving including floating with the current within the scope of the camera and organisms living on the seafloor. A few seafloor organisms - sea anemones, soft corals, sea lilies, ophiurs, polychaetes etc. - were noted. At the observation sites longline stations the seabed consisted mainly of stones, therefore there was a little benthos as benthic organisms are known to not accumulate in relatively large amounts on soft soils like silt or sand. No observations were made regarding the interaction of fishing gear with the benthic organisms, the benthic organisms on hooked-on ropes, weights and hooks. There was also no interaction of benthic organisms with the video camera and camera platform. It was clearly visible that the bottom longline as the UVS as part of the bottom fishing gear did not move along the seabed, did not touch and did not damage any sedentary organisms, except for touching at the place of landing. At the Station 9, some movement of the UVS was observed at a distance of about a few meters, which most likely was associated with the catch of the buoy on the surface by a floating iceberg.

Some gastropod mollusks were identified. Most of them are sea snails, a marine gastropod mollusk (Antarctoneptunea aurora, Buccinidae). The mollusk crawled within sight, lifting its proboscis up and forward, from

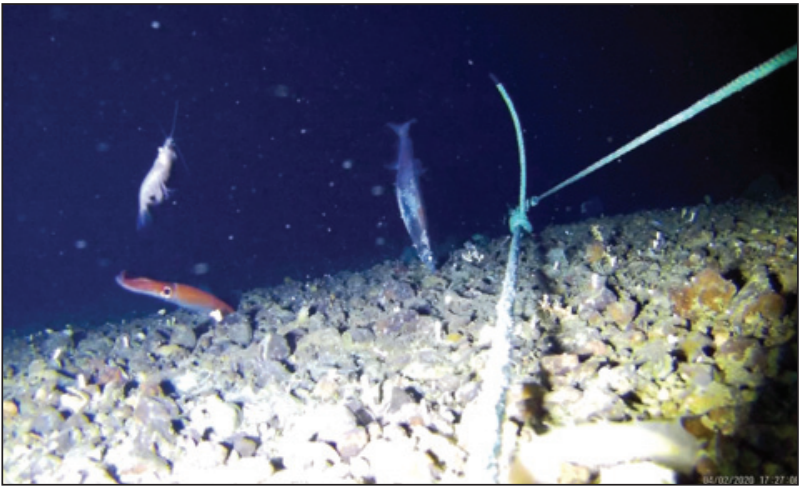

Figure 4. The video snapshot of Antarctic krill (Euphausia superba), squid (Slosarczykovia circumantarctica) and Antarctic jonasfish (Notolepis coatsi) at the depth of $1115 \mathrm{~m}$

one edge of the visible horizon to the other against the current in 15 minutes. At all three stations, a large number of Antarctic jonasfish (Notolepis coatsi, Paralepididae) was observed (Figs. 4 and 5). This species is common in Antarctic waters. Almost all the time of observations Antarctic jonasfish was seen in the camera visibility zone, sometimes dozens of them. Basically jonasfish moved at different distances from the bottom of $10-100 \mathrm{~cm}$ in one direction usually upstream (about $70 \%$ of the fish), most often at the same speed. Sometimes jonasfish moved sharply within the illuminated zone touching the bottom with the bow of the head or made circular movement. When touching the bottom the fish raised clouds of sediments (Fig. 5). This behavior was similar to the feeding process, but what this fish was eating remains unknown.

It was seen that fish egg-like particles rose from the bottom upon excitation of the surface sediment layer. So many eggs could have been laid during this observation period only by jonasfish themselves, however, to claim that they were jonasfish eggs it is necessary to have egg samples. Perhaps this species crowds up during the spawning period and at the same time feeds on its own eggs. Fish death has been recorded. One specimen of jonasfish buried its nose in the bottom and then convulsed several times and died. Its sides looked uneven, giving the impression of "peeled skin". The behavior of numerous solitary jonasfish, resting their heads against the bottom, wriggling below with simultaneous touching one another and fur- 


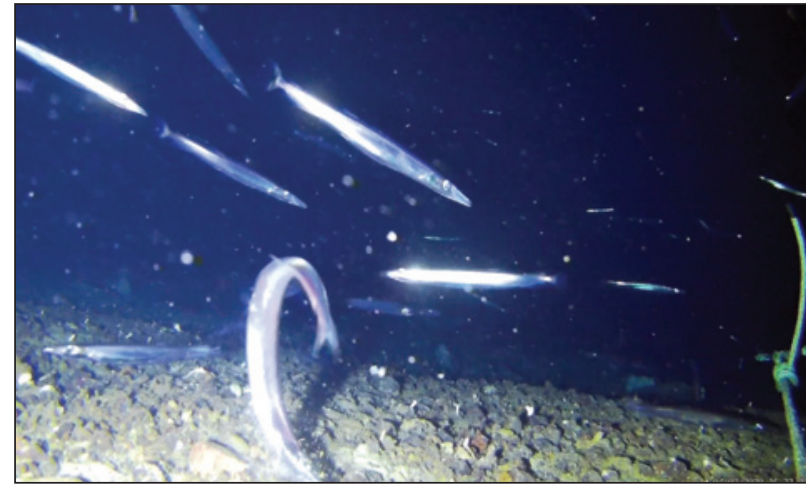

Figure 5. About 20 specimens of Antarctic jonasfish (Notolepis coatsi) seen in snapshot from video at the depth of $1115 \mathrm{~m}$

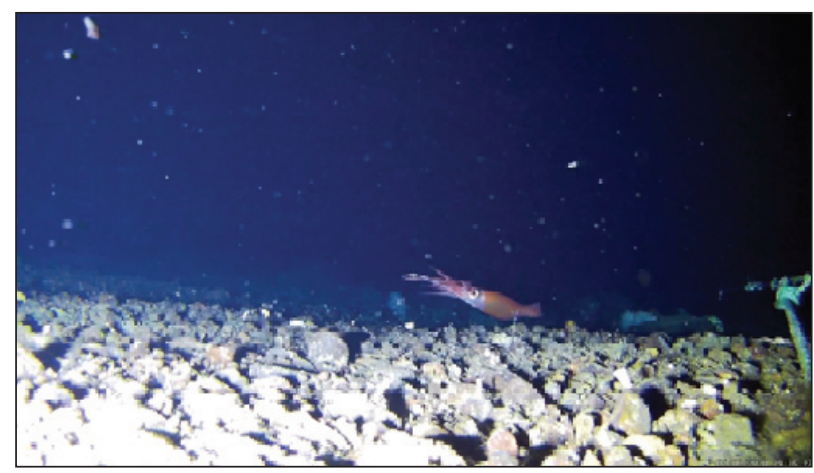

Figure 6. Squid (Slosarczykovia circumantarctica) at the depth of $1115 \mathrm{~m}$

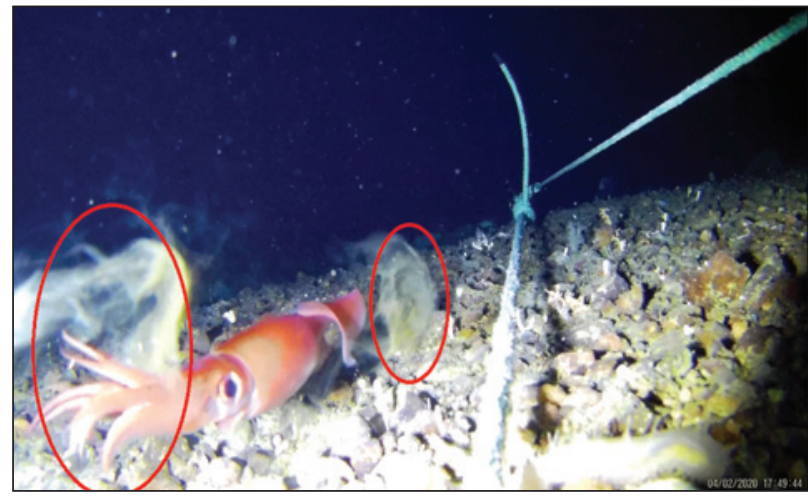

Figure 7. Spawning of squid at the depth of $1115 \mathrm{~m}$, filaments with eggs in the form of pale clouds are marked by ovals

ther accelerated twitching, occurred both near the UVS, illuminated zone, and at the border of the illuminated zone relatively far away. It seems that the entire bottom was covered by jonasfish within the fields of view of the longline stations. The size of the fish was close to the maximum size of adult jonasfish about $30 \mathrm{~cm}$. It is assumed that a detailed review of all material will allow counting all fish within the camera visibility, and on this basis, jonasfish biomass will be estimated.

Besides of Antarctic jonasfish, fish species macrourus fish (Macrourus sp., Macrourinae), Antarctic lanternfish (Electrona antarctica, Myctophidae), Dewitt's icefish (Chionobathyscus dewitti, Channichthyidae) and, probably, notothen fishes (Trematomus sp. and Dissostichus spp., Nototheniidae) were identified.

Incredibly interesting was the observation of squid at all three stations sometimes several specimens at a time (Fig. 6). The size of the mantle of the observed squid was about $120 \mathrm{~mm}$, when subsequent studies of video frames will show more accurate results. The squid species belongs to the family Brachioteuthidae and was identified as Slosarczykovia circumantarctica. The animals we observed closely resemble the descriptions by authors of (Lipinski, 2001; Filippova, 1972; Nesis, 1987; Jereb \& Roper, 2010). The snapshots from video recording show very clearly the tentacles of this squid are freely elongated. However, it completely draws the tentacles into the cavity between the arms. The squid tentacles are most often clipped to their ends, and this grip is firm. This feature allows assuming that the squid belongs to the Brachioteuthidae family. This species has a compact group of suckers at the end of the tentacle club as a locking apparatus. The tentacle clubs itself are characteristically curved in the middle. There are no hooks on the tentacles. It is known that squids of this family lay eggs in the form of thin mucous filaments to attach them to the bottom. These mucous filaments are a serosal substance covering the rows of eggs and look very delicate and easily disintegrate. At all three stations, we observed the laying of eggs by squid of this species (Fig. 7). As a rule, eggs were laid by female squid near the UVS. It seemed that the UVS attracted the females for laying eggs, squids moved in from different directions. The egg threads were instantly attached to the ground to the stones and rippled along the current. Most of the threads were probably cut off by the relatively strong current near the bottom ground. Per- 
haps the UVS attracted females blocking delicate threads with eggs from the current movement. It was not noticed that squid roe would attract Antarctic jonasfish as a food. There were also no other predators attracted by the squid eggs.

\section{Conclusions}

For the first time in Ukrainian practice the new nonextractive method for the benthic wildlife study using the UVS equipment has been provided. We found that the UVS, including shooting light, had no effect on benthic animal behavior. There are relatively few bottom animals in the observation area. No clusters of sponges, corals and other sedentary benthic animals were observed.

The UVS video observation shows the squid $S$. circumantarctica is spawning intensively at the bottom at depths of 700-1100 m. Most of the observed squids laid eggs or showed behavior close to spawning as squid females laying eggs. It allows to assume that the slope of the northeastern part of the Weddell Sea is a spawning site of squid. Probably, the peculiarity of oceanographic conditions and bottom ground with large stones on the seabed are more suitable for spawning of this species of squid. Hatching larvae will be carried out by Weddell Sea Deep and Bottom Water current flowing along the outer rim of the Weddell Gyre. From this region, when the squid larvae and juveniles emerge, Dense Shelf Water will spread east and be exported from Weddell Basin to the north to the southern periphery of the Antarctic Circumpolar Current (Kerr et al., 2018). Perhaps, in this way, the squid $S$. circumantarctica spreads from the place of mass spawning to the area of its habitat - the circumantarctic zone (Jereb \& Roper, 2010).

Current data indicate the widespread occurrence of Antarctic jonasfish south of the Antarctic divergence as stable by-catch in Antarctic krill and pelagic samples of large plankton nets, but such a high density of adult fish of known maximum size of this species in one place has never been noted. It can be assumed that in February month the jonasfish spawning occurs at the depths of 700-1100 meters when aggregations of fish spawning at the bottom, spawn- ing fish are supposed to be eliminated in the same place, larvae and fry of fish are transferred by bottom currents in the same manner as described in the previous paragraph.

There was no significant difference between the numbers of animal observed often seen in the video frame: E. superba, $S$. circumantarctica and $N$. coatsi compared between stations. At all three stations these species of animals were present and their behavior is similar.

In future we will calculate the number of benthic visible and distinguishable organisms within the camera visibility per unit area. This can allow estimating the biomass of certain species in the observed period on the survey area. A more detailed analysis will allow describing the species richness, relative abundance and size distribution in details. Similar studies using the UVS in the next season could establish the status of the area as a possible spawning ground for fish and squid, taking into account seasonality and other factors. Existing methods allow determining the sizes of animals observed by underwater devices. The measurement technique at a distance within the illuminated zone of the video camera will be developed further and applied during the next observation season. This survey ground is not a global hotspot of marine biodiversity but a small and possibly seasonal hotspot of near bottom marine biomass.

It would be useful to provide similar studies next year, and to set up the UVS stations exactly at the same places if the weather and sea ice condition allow.

Author contributions. PZ, LP: idea and draft writing. DM: organization of work and data collection. All authors have read and agreed to the published version of the manuscript.

Conflicts of Interest. The authors declare no conflict of interest.

Acknowledgments. The authors thank Bizikov V. and Bondarev I. for assistance in the invertebrate species identification.

\section{References}

Di Blasi, D., Canese, S., Carlig, E., Ghigliotti, L., Parker, S. J., \& Vacchi. M. (2018). Baited Remote Underwater Video (BRUV) system to monitor Antarctic toothfish distribution and 
abundance: pilot study results and future design. CCAMLR WG-FSA-18/62. Retrieved October 20, 2020, from https://www.ccamlr.org/ru/wg-fsa-18/62

Dunn, A., Jones, C., Mormede, S., \& Parker, S. (2016). Results of the fifth Ross Sea shelf survey to monitor abundance of sub-adult Antarctic toothfish in the southern Ross Sea, February 2016, and notification for continuation in 2017. CCAMLR WG-SAM-16/14. Retrieved October 20, 2020, from https://www.ccamlr.org/en/wg-sam-16/14

Filippova, J. A. (1972). New data on the squids (Cephalopoda: Oegopsida) from the Scotia Sea (Antarctic). Malacologia, 11, 391-406.

Garabato, A. C. N., McDonagh, E. L., Stevens, D. P., Heywood, K. J., \& Sanders, R. J. (2002). On the export of Antarctic Bottom Water from the Weddell Sea. Deep Sea Research Part II: Topical Studies in Oceanography, 49(21), 4715-4742. https://doi.org/10.1016/S0967-0645(02)00156-X

Gordon, A. L., Visbeck, M., \& Huber, B. (2001). Export of Weddell Sea deep and bottom water. Journal of Geophysical Research: Oceans, 106(C5), 9005-9017. https://doi.org/10. 1029/2000JC000281

Gutt, J., \& contributions of the participants (Eds.). (2008). The Expedition ANTARKTIS-XXIII/8 of the Research Vessel "Polarstern" in 2006/2007. Ber. Polarforsch. Meeresforsch. 569.

Hellmer, H. H., Kauker, F., Timmermann, R., \& Hattermann, T. (2017). The Fate of the Southern Weddell Sea Continental Shelf in a Warming Climate. Journal of Climate, 30(12), 4337-4350. https://doi.org/10.1175/JCLI-D-16-0420.1

Heywood, K. J., Schmidtko, S., Heuzé, C., Kaiser, J., Jickells, T. D., Queste, B. Y., Stevens, D. P., Wadley, M., Thompson, A. F., Fielding, S., Guihen, D., Creed, E., Ridley, J. K., \& Smith, W. (2014). Ocean processes at the Antarctic continental slope. Philosophical Transactions of the Royal Society A, 372(2019), Article 20130047. https://doi.org/10.1098/rsta.2013.0047

Jereb, P., \& Roper, C. F. E. (Eds.). (2010). Cephalopods of the world. An annotated and illustrated catalogue of cephalopod species known to date. Volume 2. Myopsid and Oegopsid Squids. FAO Species Catalogue for Fishery Purposes. No. 4, Vol. 2. FAO. Retrieved October 20, 2020, from http://www.fao.org/3/i1920e/ i1920e00.htm
Jones, C. D., \& Lockhart, S. J. (2011). Detecting Vulnerable Marine Ecosystems in the Southern Ocean using research trawls and underwater imagery. Marine Policy, 35(5), 732-736. https:// doi.org/10.1016/j.marpol.2011.02.004

Kerr, R., Dotto, T. S., Mata, M. M., \& Hellmer, H. H. (2018). Three decades of deep water mass investigation in the Weddell Sea (1984-2014): Temporal variability and changes. Deep-Sea Research Part II: Topical Studies in Oceanography, 149, 70-83. https://doi.org/10.1016/j.dsr2.2017.12.002

Lipinski, M. R. (2001). Preliminary description of two new species of Cephalopods (Cephalopoda: Brachioteuthidae) from South Atlantic and Antarctic waters. Bulletin of the Sea Fisheries Institute, 1(152), 3-14.

Lockhart, S., Wilson, N., Lazo-Wasem, E., \& Jones, C. (2009). Benthic Invertebrate Composition and Characterization of the South Orkney Islands. 2008-2009 Field Season AMLRP Report (Chapter 10, pp. 67-75). NOAA-TM-NMFS-SWFSC-445. Antarctic Ecosystem Research Division, Southwest Fisheries Science Center.

Maschette, D., Lamb, T., Welsford, D., Yates, P., \& Ziegler, P. (2016). Report on the collection of environmental data during exploratory fishing by Australia in Division 58.4.1 during the 2015/16 fishing season. CCAMLR WG-SAM-16/34.

Nesis, K. N. (1987). Cephalopods of the World: Squids, Cuttlefishes, Octopuses and Allies (1st ed.). Tropical Fish Hobbyist Publications, Inc.

Orsi, A. H., Johnson, G. C., \& Bullister, J. L. (1999). Circulation, mixing, and production of Antarctic Bottom Water. Progress in Oceanography, 43(1), 55-109. https://doi.org/10. 1016/S0079-6611(99)00004-X

Vernet, M., Geibert, W., Hoppema, M., Brown, P. J., Haas, C., Hellmer, H. H., Jokat, W., Jullion, L., Mazloff, M., Bakker, D. C. E., Brearley, J. A., Croot, P., Hattermann, T., Hauck, J., Hillenbrand, C.-D., Hoppe, C. J. M., Huhn, O., Koch, B.P., Lechtenfeld, O. J., ... \& Verdy, A. (2019). The Weddell Gyre, Southern Ocean: Present knowledge and future challenges. Reviews of Geophysics, 57(3), 623-708. https://doi.org/10.1029/ 2018RG000604

Received: 29 October 2020 Accepted: 28 December 2020

\section{П. Заброда ${ }^{1}$, Л. Пшеничнов ${ }^{1, *}$, Д. Марічев ${ }^{2}$}

${ }^{1}$ Інститут рибного господарства та екології моря (IPEM), м. Бердянськ, 71118, Україна

${ }^{2}$ Рибальська компанія «Нептуно», м. Одеса, 67500, Україна

*Автор для кореспонденції: 1kpbikentnet@gmail.com

\section{Спостереження бентосу підводною відеосистемою під час ярусної зйомки в морі Ведделла}

Реферат. Неекстракційний метод дослідження бентосних організмів з використанням підводної відеосистеми (UVS) був реалізований під час наукових досліджень за допомогою донного яруса в підрайоні північно-західної частини моря Ведделла. На станціях ярусних постановок були зібрані й інші дані, такі як: напрямок і швидкість вітру, хвилі, температура повітря, хмарність, концентрація льоду, атмосферний тиск, опади, глибина і координати встановлення 
якорів, напрямок встановлення ярусів. Було проведено три успішні постановки підводних відеосистем на схилі шельфу Антарктиди. Національним науковим спостерігачем спільно з екіпажем судна відпрацьована методика постановки UVS і збереження даних відео спостережень. В результаті проведених досліджень можна зробити висновок, що пристрої UVS, включаючи освітлення, не впливали на поведінку тварин у досліджуваній зоні на глибинах 700-1100 м, а також що схил північно-західної частини моря Ведделла є місцем нересту кальмарів Slosarczykovia circumantarctica. Отримані дані свідчать про широке поширення Euphausia superba та Notolepis coatsi. Висока щільність дорослих риб N. coatsi в одному місці ніколи не відзначалася. Попередній аналіз відеозаписів показав, що відстань освітлення і спостереження достатні для проведення дослідження та фіксації тварин, їх відеофіксації та ідентифікації, а також спостереження за їхньою поведінкою і способом дії. Більш детальний аналіз дозволить досить докладно описати біорізноманіття, відносну чисельність та розміри риб й інших тварин. У лютому 2021 року заплановано продовжити дослідження за допомогою підводної відеосистеми в тому ж районі Південного океану.

Ключові слова: антарктична риба джонас, донний ярус, кальмар, криль, море Ведделла, нерест, підводна відеосистема, поведінка тварин 